\section{Primäre Schlafapnoe im Säuglingsalter}

Helga Peter

Marburg, Deutschland

\section{Englischer Begriff}

primary sleep apnea of infancy

\section{Definition}

Zählt in der ICSD-2 zur Diagnosegruppe der $>$ „Zentrale Schlafapnoesyndrome“; wurde in der ICSD von 1991 als Primäre Schlafapnoe des Neugeborenen bezeichnet.

Siehe auch

- $>$,Kindesalter“

- „Schlafbezogene Atmungsstörungen“ 